Article

\title{
Interacting Controls of Pyrolysis Temperature and Plant Taxa on the Degradability of PyOM in Fire-Prone Northern Temperate Forest Soil
}

\author{
Christy D. Gibson ${ }^{1,2}(\mathbb{D})$, Pierre-Joseph Hatton ${ }^{3}$, Jeffrey A. Bird ${ }^{4,5}\left(\mathbb{D}\right.$, Knute Nadelhoffer ${ }^{3}(\mathbb{D})$, \\ Collin P. Ward ${ }^{6}$ (D), Ruth E. Stark ${ }^{5,7}$ (iD) and Timothy R. Filley ${ }^{1,2,8, * \text { (I) }}$ \\ 1 Department of Earth, Atmospheric and Planetary Sciences, Purdue University, West Lafayette, IN 47906, \\ USA; gibson50@purdue.edu \\ 2 Purdue Climate Change Research Center, Purdue University, West Lafayette, IN 47906, USA \\ 3 Department of Ecology and Evolutionary Biology, University of Michigan, Ann Arbor, MI 48109, USA; \\ hatton_pj@yahoo.fr (P.-J.H.); knute@umich.edu (K.N.) \\ 4 School of Earth \& Environmental Sciences, Queens College, City University of New York, Flushing, \\ NY 11367, USA; jbird@qc.cuny.edu \\ 5 The Graduate Center, City University of New York, New York, NY 11367, USA; rstark@ccny.cuny.edu \\ 6 Department of Marine Chemistry and Geochemistry, Woods Hole Oceanographic Institution, Woods Hole, \\ MA 02360, USA; cward@whoi.edu \\ 7 Department of Chemistry and Biochemistry, The City College of New York and CUNY Institute for \\ Macromolecular Assemblies, New York, NY 10031, USA \\ 8 Department of Agronomy, Purdue University, West Lafayette, IN 47906, USA \\ * Correspondence: filley@purdue.edu; Tel.: +1-765-494-6581
}

Received: 4 June 2018; Accepted: 28 July 2018; Published: 14 August 2018

Abstract: Tree taxa and pyrolysis temperature are the major controllers of the physicochemical properties of the resultant pyrogenic organic matter (PyOM) produced in fire-prone forests. However, we know little about how these controls determine the residence time of PyOM once introduced to soil. In this study, we tracked the fate of ${ }^{13} \mathrm{C}$-enriched red maple (RM) or jack pine (JP) wood and PyOM, produced over a range of temperatures $\left(200,300,450\right.$, or $\left.600{ }^{\circ} \mathrm{C}\right)$ added to soil from a northern temperate forest in Michigan, USA. Pyrolysis temperature was the main controller of PyOM-C mineralization rates, with mean residence times (MRT) ranging from $\sim 4$ to 450 years for both taxa. The PyOM-C mineralization rates for both taxa and the pyrolysis temperature correlated positively with $\mathrm{PyOM}_{\mathrm{w}}$ (leachable $\mathrm{C}$ content); however, the potential $\mathrm{PyOM}_{\mathrm{w}}$ contribution to net PyOM-C mineralization was lower for JP (14-65\%) than RM (24-84\%). The correlation between $\mathrm{PyOM}_{\mathrm{w}}$ and mineralization rate was strongest where carbonization and the thermochemical conversion of carbohydrates and non-lignin phenols was most pronounced during pyrolysis for each taxa $\left(300{ }^{\circ} \mathrm{C}\right.$ for JP and $450{ }^{\circ} \mathrm{C}$ for RM). Contrary to expectations, the addition of a labile $\mathrm{C}$ source, sucrose, to the soil did not enhance the decomposition of PyOM, indicating that soil microbes were not energy limited in the soil-PyOM system studied (regardless of pyrolysis temperature). Our results showed that while the first-order control on PyOM decomposition in this soil is pyrolysis temperature, wood taxa did affect PyOM-C MRT, likely in part due to differences in the amount of reactive water-soluble $\mathrm{C}$ present in PyOM.

Keywords: pyrogenic organic matter; decomposition; stabilization; soil organic matter; recalcitrance; labile organic matter; fire; forest soil 


\section{Introduction}

Addition rates of pyrogenic organic matter (PyOM), the product of the incomplete biomass combustion, to soils are expected to increase globally with projected increases in fire frequency $[1,2]$. PyOM in soil can constitute a substantial portion of stable forest soil C (up to 20\%) and as a result, accurate estimates of PyOM reactivity and mean residence time (MRT) in soil are needed [2-4]. Increased PyOM deposition and its consequent reactivity and MRT in soil will be particularly important in fire-prone ecosystems which are also experiencing shifts in plant species dominance, the impacts of which are still unknown $[5,6]$. While many studies have attempted to quantify how plant taxa and PyOM production temperature interact to control native soil C dynamics in a PyOM-soil system, few of these studies (32), to our knowledge, have incorporated an isotopic label to uniquely quantify PyOM-C dynamics as distinct from soil-C [7-9]. Of these experiments, 14 involved incubations longer than 180 days, six used well-characterized wood-derived PyOM, and two utilized PyOM materials produced at a range of production temperatures as well as the associated unaltered parent materials (Supplemental Information, Table S1). Given the limited number of studies designed to track the fate of PyOM-C, a significant gap remains in PyOM-C turnover dynamics and further investigation is needed to predict its mineralization and stability in a changing climate.

The MRT of PyOM in soil is greater than the plant material from which it originates, and many other forms of natural organic matter $[7,10]$ with decadal to centennial, or, in rare cases, millennial residence times have been reported $[4,7,11,12]$. It is assumed that the first-order control on PyOM reactivity in soil is determined by the pyrolysis of the initial plant material, whereby PyOM becomes progressively condensed and aromatized with increasing pyrolysis temperature $[5,13,14]$. While PyOM may persist for long periods of time in soil due to its acquired physicochemistry and the promotion of stabilization through soil aggregation $[15,16]$, it is susceptible to both abiotic and biotic decomposition processes, which are influenced by the soil microbial community composition [17-19], soil edaphic properties [8], and exposure to chemical and photo oxidants [20-23]. Direct microbial degradation has been extensively documented. Decay studies of PyOM have demonstrated that the complex consortia of bacteria and fungi present in soil are capable of PyOM degradation through the release of oxidative and hydrolytic enzymes [19,23-25]. However, microbial degradation varies based upon source plant taxa, temperature of production, and the proportion, chemistry, and availability of unaltered biomass within PyOM [26-28]. In addition, inputs of exogenous labile $C$ or soluble $C$ in the form of root exudates and simple carbohydrates such as glucose, or soluble $C$ such as litter dissolved organic $C$ (DOC) [29-31], have been shown to enhance PyOM decay, suggesting that co-metabolic energy supply may be important in controlling PyOM turnover in soils.

The temperature experienced by biomass during natural fires can vary widely within single events and across ecosystem types; natural grass and shrub fire temperatures can range from $\sim 100-500{ }^{\circ} \mathrm{C}$, while forest fires range from $\sim 300-900{ }^{\circ} \mathrm{C}[32,33]$. Under conditions of depleted oxygen, i.e., pyrolysis, and at the lower temperatures $\left(\sim>100-250{ }^{\circ} \mathrm{C}\right)$ significant proportions of the cellulose, hemicellulose, and lignin chemistry as well as the wood ultrastructure are maintained. Above these temperatures, however, important physical and chemical transformations occur across temperature ranges that, in turn, depend on plant taxa and oxygen content $[11,12,30]$. Temperatures ranging from about $>250-450^{\circ} \mathrm{C}$ represent an energy threshold where decarboxylation, dehydration, and some carbonization is initiated. At pyrolysis temperatures $>450{ }^{\circ} \mathrm{C}$, amorphous and highly condensed polyaromatic structures form $[5,13,34]$. Thermal alteration patterns may vary based on the initial plant chemistry [12]; this is an important consideration, as biomass type can vary extensively within fire-prone ecosystems [35-37]. The degree of structural and chemical alteration of woody tissue along a pyrolysis temperature gradient from $200-600{ }^{\circ} \mathrm{C}$ was strongly dependent upon source taxa; carbonization, the loss of carbohydrates, non-lignin phenols, and the formation of intermediate thermally-stable aliphatic compounds occurred at lower pyrolysis temperatures for jack pine (Pinus baksiana) compared to red maple (Acer rubrum). Similar differences in thermal transition points were observed in structural and surface property transformations and were also found to be 
taxa-dependent $[5,38,39]$. The potential impact of this structural and molecular variability as a result of PyOM source and pyrolysis has important implications for PyOM turnover in soils [40].

Our goal in this experiment was to better understand the effects of shifts in plant taxa on PyOM reactivity and MRT in a soil from a fire-prone ecosystem. To accomplish this, we investigated how the physiochemical properties of PyOM derived from two common taxa-jack pine (Pinus baksiana) and red maple (Acer rubrum), produced across a range of relevant temperatures (200, 300, 450, and $600{ }^{\circ} \mathrm{C}$ ) - control PyOM mineralization rate in a soil system common to northern Great Lakes forests that are expected to experience shifts in forest taxa and fire frequency. The forest soil we investigated is similar to much of the northern temperate/boreal forest soils in North America that developed after the most recent glacial event. Consequently, the stabilization capacity of these weakly developed coarse soils is generally low, with approximately $50-55 \%$ of the soil organic C (SOC) at the surface $(0-15 \mathrm{~cm}$ depth) at this site in the free light fraction, which is either unprotected or weakly protected [41]. This work differs from previous studies in that a wide range of pyrolysis temperatures was investigated using two tree taxa including initial wood. Precursor wood in both taxa used was uniformly ${ }^{13} \mathrm{C}$-labeled prior to pyrolysis to allow the unequivocal assessment of decay rates. Also, the wood and PyOM used in this study have been extensively characterized in their physiochemical properties and were added to soils at ecologically relevant loading rates ( $11 \%$ of total SOC). We sought to (1) determine how physiochemical differences affect PyOM decomposition and MRT, (2) estimate the proportion of PyOM reactive (fast-cycling C) and inert pools (slow-cycling C), and (3) determine characteristics that best predict PyOM reactivity.

We hypothesized that: (1) pyrolysis temperature, rather than plant taxa, would be the first-order control of PyOM decomposition and the overall MRT of PyOM would increase with increasing pyrolysis temperature; (2) differences in the initiation temperatures of thermochemical conversion between the two taxa would manifest in distinct pyrolysis temperature controls on PyOM decay and MRT; (3) water-extractable $\mathrm{C}$ content $\left(\mathrm{PyOM}_{\mathrm{w}}\right)$, a measure of reactive $\mathrm{C}$, would correlate strongly with PyOM decomposition rates; and (4) the addition of exogenous labile $\mathrm{C}$, i.e., sucrose, would have a limited influence on PyOM decomposition above $450{ }^{\circ} \mathrm{C}$ for either taxa and for the carbohydrate-rich red maple PyOM, but would markedly increase decomposition rates in the lignin-rich jack pine PyOM $\left(<450{ }^{\circ} \mathrm{C}\right)$.

\section{Materials and Methods}

\subsection{Physcial and Chemical Characterization of ${ }^{13} C$-Enriched PyOM and Source Wood}

Saplings are vulnerable to charring and deposition during wildfires and thus were chosen as the feedstock for PyOM production in this study [25,33,42]. Detailed PyOM production and physiochemical characterization of the PyOM and wood used in this study were published in Hatton et al. [5]. Briefly, 1-year-old jack pine (30-40 cm height; Itasca Greenhouse Inc., Cohasset, MN, USA) and 2-year-old red maple saplings (30-60 cm height; Cold Stream Farms, Freesoil, MI, USA) were grown in a soil matrix consisting of washed sand and fritted clay under ${ }^{13} \mathrm{CO}_{2}$ (25 atom\%) [43]. Barked stems (wood biomass) from the pine and maple saplings were dried at $25^{\circ} \mathrm{C}$ and cut into $1-2 \mathrm{~cm}$ pieces before being pyrolyzed in the absence of oxygen under a stream of $\mathrm{N}_{2}$ for $5 \mathrm{~h}$, as described by Hammes et al. [44], at 200, 300, 450, and $600{ }^{\circ} \mathrm{C}$. The precursor wood and PyOM material were ground to $1 \mathrm{~mm}$ before being amended to soil. Subsamples of each PyOM and wood source were homogenized by ball milling prior to elemental, stable isotope, and other physiochemical analyses; the results of which were presented in Hatton et al. [5]. Isotopic analysis revealed that ${ }^{13} \mathrm{C}$ ratios did not significantly vary across the production temperature gradient, indicating a uniformly labeled material. Detailed chemical and isotope characteristics of the soil, wood, and PyOM amendments are shown in Table 1. Descriptions of analytical thermal and gravimetric analyses were provided in Hatton et al. [5]. Briefly, based on the methods of Fernandez et al. [45], the total exothermic energy content (J) of PyOM was calculated by integrating the resulting heat flux thermograms of differential scanning calorimetry (DSC) 
over the region of $150-650^{\circ} \mathrm{C}$ (exothermic), and then normalizing by $\mathrm{mg}$ of $\mathrm{C}$ (energy density). The term "energy density" is used as a measure of the presence of energy-rich structures in PyOM which can provide an estimate of the degradability of PyOM and wood in natural systems [5]. To determine the percent composition of long-chain aliphatic $C$ and carbohydrate $C$ in the materials, the areas within the solid state nuclear magnetic resonance spectra were integrated within specific band ranges, as detailed in Hatton et al. [5]. The unitless recalcitrance index is defined as the temperature by which half the mass of the wood and PyOM is lost divided by the temperature at which half the mass of the standard graphite is lost. Water-extractable $\mathrm{PyOM}\left(\mathrm{PyOM}_{\mathrm{W}}\right)$ was operationally defined as organic $\mathrm{C}$ that passed through a pre-combusted Whatman GF/F (glass fiber/fiber) filter $\left(450{ }^{\circ} \mathrm{C}\right.$ for $4 \mathrm{~h}$; nominal pore size $0.7 \mu \mathrm{m})$. Suspensions of $1.25 \mathrm{~g}$ of PyOM per liter of lab-grade deionized water were adjusted to a $\mathrm{pH}$ of $8.0 \pm 0.1$ using dilute solutions of sodium hydroxide and equilibrated on a shaker table in the dark at room temperature for $48 \mathrm{~h}$. Following equilibration, the suspensions were GF/F-filtered and triplicate aliquots of the filtrate were characterized for total organic carbon (TOC) content and absorbance at $254 \mathrm{~nm}$. TOC content was determined using high-temperature catalytic combustion using potassium hydrogen phthalate as the calibration standard. Light absorbance at $254 \mathrm{~nm}$ was quantified using an Aqualog spectrophotometer (Horiba Scientific) and a 1-cm quartz cuvette. Specific ultraviolet

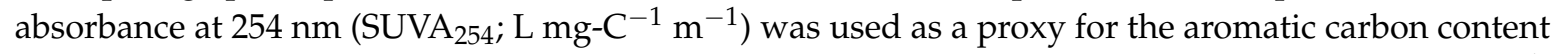
of $\mathrm{PyOM}_{\mathrm{w}}[46,47]$ and was calculated by dividing the decadic absorbance coefficient at $254\left(\mathrm{~m}^{-1}\right)$ by the TOC content of $\mathrm{PyOM}_{\mathrm{w}}\left(\mathrm{mg}-\mathrm{C} \mathrm{L}^{-1}\right)$. To estimate the proportion of aromatic C in $\mathrm{PyOM}_{\mathrm{w}}$, specific UV absorption (SUVA) at $254 \mathrm{~nm}$ was measured. Detailed chemical characteristics are shown in Table 1. Where possible, jack pine and red maple are referred to as JP and RM, respectively. 
Table 1. Elemental composition and isotopic composition of jack pine (JP) and red maple (RM) pyrogenic organic matter (PyOM) and source wood, porosity, Brunauer-Emmett-Teller (BET) surface area, energy density, \% non-lignin phenols, recalcitrance index ( $\left.\mathrm{R}_{50}\right)$, specific UV absorption at $254 \mathrm{~nm}(\mathrm{SUVA})$, PyOM $\mathrm{W}$ (\% leachable PyOM of initial PyOM or wood), and energy density for jack pine and red maple PyOM source wood, as well as for PyOM produced at 200, 300, 450, and $600{ }^{\circ} \mathrm{C}$. Percentage composition estimated by DPMAS ${ }^{13} \mathrm{C}$ NMR spectroscopy for jack pine and red maple wood and PyOM $300-450{ }^{\circ} \mathrm{C}$. NMR estimates were derived from peak intensities as follows: (i) long-chain aliphatics (0-45 ppm); carbohydrates (45-110 ppm) for precursor wood sources and (ii) long-chain aliphatics (0-45 ppm), aliphatic (45-90 ppm) for PyOM. Neither long-chain aliphatics nor carbohydrates are visible in the JP T600 or RM T600 spectra. Measurements for jack pine T200 and red maple T200 were based on CPMAS ${ }^{13} \mathrm{C}$ NMR data [5]. Non-lignin phenols were quantified via ${ }^{13} \mathrm{C}$ thermally assisted chemolysis (TMAH) [5]. $\mathrm{R}_{50}$ and energy density were determined by differential scanning calorimetry (DSC) and thermogravimetric analysis (TGA). Specific UV absorption (SUVA) of leached wood and PyOM was obtained at $254 \mathrm{~nm}$ light, and leached wood and $\mathrm{PyOM}_{\mathrm{w}}$ was determined via water extraction.

\begin{tabular}{|c|c|c|c|c|c|c|c|c|c|c|c|c|c|c|}
\hline Treatment & $\underset{\left(\mathrm{g} \mathrm{kg}^{-1}\right)}{\mathrm{C}}$ & $\underset{\left(\mathrm{g} \mathrm{kg}^{-1}\right)}{\mathrm{N}}$ & $\begin{array}{c}{ }^{13} \mathrm{C} \\
\text { (atom \%) }\end{array}$ & $\begin{array}{c}{ }^{15} \mathrm{~N} \\
\text { (atom \%) }\end{array}$ & $\begin{array}{l}\text { Porosity } \\
(\%)\end{array}$ & $\begin{array}{l}\text { BET-N } N_{2} \text { Surface } \\
\text { Area }\left(\mathrm{m}^{2} \mathrm{~g}^{-1}\right)\end{array}$ & $\begin{array}{l}\text { \% Long-Chain } \\
\text { Aliphatics }\end{array}$ & $\begin{array}{l}\text { \% Non-Lignin } \\
\text { Phenols }\end{array}$ & $\begin{array}{c}\% \\
\text { Carbohydrates }\end{array}$ & $\begin{array}{l}\text { Recalcitrance } \\
\text { Index }\left(\mathbf{R}_{50}\right)\end{array}$ & $\begin{array}{r}\text { Speci } \\
\text { Abso } \\
(254\end{array}$ & $\begin{array}{l}\text { fic UV } \\
\text { rption } \\
\text { (nm) }\end{array}$ & $\begin{array}{c}\text { \% Leachable } \\
\text { PyOM of Initial } \\
\text { PyOM or Wood } \\
\left(\text { PyOM }_{w}\right)\end{array}$ & $\begin{array}{c}\text { Energy } \\
\text { Density } \\
\left(\mathrm{J} \mathrm{mg}^{-1} \mathrm{C}\right)\end{array}$ \\
\hline JP wood & 464 & 2.8 & 2.2 & 19.2 & 53 & 2.6 & 10.7 & 21.2 & 58.7 & 0.4 & 1.1 & $<0.01$ & 7.4 & 21.1 \\
\hline JP T200 & 507 & 3.4 & 2.4 & 18.8 & 60 & 2.8 & 10.6 & 18.3 & 67.6 & 0.4 & 1.7 & $<0.01$ & 4.2 & 20.2 \\
\hline JP T300 & 669 & 5.4 & 2.4 & 18.8 & 75 & 4.3 & 22.1 & 5.9 & 15.8 & 0.5 & 1.7 & $<0.01$ & 1.4 & 26.4 \\
\hline JP T450 & 786 & 5.4 & 2.3 & 18.9 & - & 13 & 7.7 & 0.09 & 6.8 & 0.5 & 3.2 & 0.10 & 0.3 & 27.2 \\
\hline JP T600 & 831 & 5.3 & 2.3 & 18.8 & - & 212 & 0.0 & 3.3 & 0.0 & 0.6 & 3.7 & 0.10 & 0.4 & 26.9 \\
\hline RM wood & 451 & 6.4 & 3.8 & 8.9 & 60 & 0.5 & 13.7 & 63.1 & 65.1 & 0.4 & 2.6 & 0.10 & 11.8 & 20.0 \\
\hline RM T200 & 495 & 6.9 & 3.8 & 8.9 & 61 & 1.4 & 12.3 & 36.9 & 65.1 & 0.4 & 3.1 & $<0.01$ & 8.1 & 22.2 \\
\hline RM T300 & 574 & 9.0 & 3.7 & 8.9 & 72 & 2.3 & 19.4 & 14.3 & 41.4 & 0.4 & 2.4 & $<0.01$ & 4.4 & 23.4 \\
\hline RM T450 & 761 & 9.4 & 3.9 & 9.1 & 78 & 3.3 & 5.7 & 0.62 & 4.5 & 0.5 & 3.0 & 0.10 & 0.4 & 30.5 \\
\hline RM T600 & 765 & 9.5 & 3.9 & 9.2 & 81 & 132 & 0.0 & 0.01 & 0.0 & 0.5 & 4.0 & 0.10 & 0.4 & 29.6 \\
\hline
\end{tabular}




\subsection{Soil Sampling and Laboratory Incubation Experiments}

In 2012, the soils used in this study were sampled from four locations (field blocks) to a depth of $20 \mathrm{~cm}$ from a 1-ha burn plot (experimentally burned in 1980, previously burned in 1911 in a region-wide, post-harvest fire) located within the University of Michigan Biological Station (UMBS) Fire Chronosequence Study. UMBS is located in Pellston, MI, USA along the northern temperate/boreal forest boundary $\left(45^{\circ} 35.5^{\prime} \mathrm{N}, 84^{\circ} 43^{\prime} \mathrm{W}\right)$. Soils were sieved to $2 \mathrm{~mm}$, air-dried, and homogenized within each field block by gentle tumbling. The soils are described as excessively well-drained, medium, frigid Typic Orthods with a composition of $92 \mathrm{~g}$ sand $\mathrm{kg}^{-1}, 7 \mathrm{~g}$ silt kg${ }^{-1}$, and $1 \mathrm{~g} \mathrm{clay} \mathrm{kg}^{-1}$ [48,49]. Soil C in the top $15 \mathrm{~cm}$ of mineral soil at this site exists predominantly in the free light fraction (50-55\% of organic C) with a mean residence time of $\sim 170$ years, respectively [41]. The forest is experiencing shifts in tree species dominance moving from big-tooth aspen (Populus grandidentata) and approaching red maple (Acer rubrum) and oak (Quercas rubra) canopy dominance with an admixture of red and white pine (Pinus strobus and Pinus resinosa) and birch (Betula papyrifera) $[48,49]$.

Each PyOM or wood type was added at $11 \%$ of SOC to $20 \mathrm{~g}$ of soil $\left(\delta^{13} \mathrm{C}=-28 \%\right.$ ) in seperate 20-mL scintillation vials (Sigma Aldrich, St. Louis, MO, USA). This addition rate is within the range of litter input at this site [48] and within the natural limits of fire-affected biomass conversion to PyOM (up to $\sim 25 \%$ ) [33]. No PyOM treatments served as controls. Each species $\times$ temperature treatment was replicated at the block $(n=4)$ level. Autoclaved water was then added to bring soils to $60 \%$ water holding capacity $\left(\sim 0.22 \mathrm{~mL} \mathrm{~g}^{-1}\right.$ soil). To determine the interactive effect of labile DOC on PyOM mineralization, beet sucrose $\left(\delta^{13} \mathrm{C}=-28 \%\right.$ ) solutions $\left(0.15 \mathrm{mg} \mathrm{g}^{-1}\right.$ soil $)$ were added to half of the samples at $60 \%$ water holding capacity (WHC). Five assembled scintillation vials, the equivalent of $100 \mathrm{~g}$ soil altogether, were added to one 1-L Mason jar containing $20 \mathrm{~mL}$ of autoclaved water and sealed with self-sealing lids fitted with natural rubber septa. Prior to incubation and at each sampling point, jars were flushed with humidified $\mathrm{CO}_{2}$-free air, 10 times the headspace volume to prevent $\mathrm{CO}_{2}$ saturation, and stored in the dark in a temperature-controlled room, $\mathrm{T}=26 \pm 1{ }^{\circ} \mathrm{C}$. Room temperature was monitored using an Amprobe T300 temperature and relative humidity monitor (Amprobe, Seattle, WA, USA). Experimental conditions (WHC, temperature, relative humidity, and darkness) were chosen to simulate summer field conditions in which microbial activity is expected to be highest [50]. Jar headspace was subsampled and injected into pre-evacuated Exetainer vials on days 1, 3, 5, 11, 17, $26,60,90,120,160,200$, and 300 after initiation.

\subsection{Stable Isotope Measurements}

Collected gas samples were analyzed for $\mathrm{CO}_{2}$ concentration and ${ }^{13} \mathrm{C}-\mathrm{CO}_{2}$ isotope enrichment using a Sercon Cryoprep TG2 interfaced to a Sercon 20-22 Hydra Isotope Ratio Mass Spectrometer (IRMS) (Sercon, Crewe, UK).

The fraction (f) of PyOM or wood-derived $\mathrm{C}$ were calculated from these measurements as follows:

$$
\mathrm{fPyOM}=\frac{\text { Atom } \%{ }^{13} \mathrm{CO}_{2 \text { sample }}-\text { Atom } \%{ }^{13} \mathrm{CO}_{2 \text { standard }}}{\text { Atom } \%{ }^{13} \mathrm{C}_{\mathrm{PyOM}}-\text { Atom } \%{ }^{13} \mathrm{C}_{\text {soil }}}
$$

\subsection{Curve Fitting, Correlative and Statistical Analyses}

A double exponential decay model was applied to the rate curve to determine cumulative PyOM mineralized to $\mathrm{CO}_{2}$, following Santos et al. [18]. Two conceptual carbon pools (fast and slow) were also partitioned using this model

$$
\mathrm{dc} / \mathrm{dt}=\mathrm{C}_{\mathrm{F}} \mathrm{e}^{\mathrm{k}_{\mathrm{Ft}}}+\mathrm{C}_{\mathrm{S}} \mathrm{e}^{\mathrm{k}_{\mathrm{St}}}
$$

where $C_{F}$ and $C_{S}$ are the fast- and slow-cycling $C$ pools, respectively, and $k_{F}$ and $k_{S}$ are the rate constants for the fast- and slow-cycling $\mathrm{C}$ pools $\left(\mathrm{mg} \mathrm{C}\right.$ day $\left.^{-1}\right)$. The total size of these pools was calculated by integrating the first-order equation for each pool from Equation (3): 


$$
\mathrm{C}_{\mathrm{ti}}=\mathrm{C}_{\mathrm{i}} /-\mathrm{k}_{\mathrm{i}}\left(\mathrm{e}^{\mathrm{k}_{\mathrm{ii}}}-1\right)
$$

To calculate the MRT of the $\mathrm{C}_{\mathrm{F}}$ and $\mathrm{C}_{\mathrm{S}}$ conceptual pools, the amount of PyOM remaining from the initial PyOM added at each discrete interval, $t$, was also fit to a double exponential decay model, similar to that in Equation (4):

$$
\mathrm{C}_{\text {remaining }}=\mathrm{R}_{\mathrm{F}} \mathrm{e}^{\mathrm{k}_{\mathrm{F}}}+\mathrm{R}_{\mathrm{S}} \mathrm{e}^{\mathrm{k}_{\mathrm{S}}}
$$

where $R_{F}$ and $R_{S}$ are the fast- and slow-cycling $C$ pools, respectively, $k_{F}$ and $k_{S}$ are the decay constants for the fast- and slow-cycling $C$ pools, and $t$ is the discrete time interval in days. The MRT of the fastand slow-cycling $C$ pools was calculated by taking the inverse of the absolute decay constant for each pool (Equation (5)):

$$
\mathrm{MRT}_{\mathrm{i}}=1 / \mathrm{k}_{\mathrm{i}}
$$

where $\mathrm{MRT}_{\mathrm{i}}$ is the mean residence time of the given pool and $\mathrm{k}_{\mathrm{i}}$ is the decay constant.

$\mathrm{PyOM}_{\mathrm{w}}$ content (mg C; Table 2) of initially added wood and PyOM was calculated by multiplying the \% leachable PyOM (Table 1$)$ by the amount of PyOM added $(\mathrm{mg} \mathrm{C})$ at the beginning of the experiment. To estimate the potential contribution (\%) of $\mathrm{PyOM}_{\mathrm{w}}$ to the net $\mathrm{PyOM}$ mineralization, $\mathrm{PyOM}_{\mathrm{w}}$ was divided by the net PyOM mineralized (i.e., the integrated total $\mathrm{CO}_{2}$-C released) and the resultant value was multiplied by 100 (Table S2).

Curve fitting was performed in Matlab 2014a (Mathworks, Natick, MA, USA). The Levenberg-Marquadt algorithm was applied to estimate parameters and reduce the sum of squares between the observed and modeled values. A full factorial ANOVA was performed to determine interactive source taxa, production temperature, and sucrose addition effects on wood and PyOM mineralization and MRT. Post hoc Tukey tests were also performed to determine significant differences between specific treatments. To determine the link between the thermal alteration of PyOM and its mineralization and MRT, Pearson product moment correlation coefficients were determined for selected parameters (Tables 1 and S3) at each temperature for both jack pine and red maple. Samples that were not normally distributed were $\log ^{10}$ transformed before analyses. Correlative analysis and ANOVA were performed in SAS JMP 12 (SAS Institute Inc., Cary, NC, USA). All analyses were performed at a $95 \%$ confidence interval unless otherwise specified. 
Table 2. Net mineralization (mg PyOM-C mineralized $\mathrm{g}^{-1}$ soil $\mathrm{C}$ ), the size of the fast-cycling $\mathrm{C}$ pool $\left(\mathrm{C}_{\mathrm{F}} ; \mathrm{mg} \mathrm{C}^{-1}\right.$ soil $\left.\mathrm{C}\right)$ and the slow-cycling $\mathrm{C}$ pool $\left(\mathrm{C}_{\mathrm{S}}\right.$; mg $\mathrm{C} \mathrm{g}^{-1}$ soil C), mean redisdence time (MRT) of the fast- and slow-cycling $\mathrm{C}$ pools (days and years, respectively), and the PyOM $\mathrm{M}_{\mathrm{w}}$ content (mg $\mathrm{C}$ ) for jack pine and red maple without sucrose (top) and jack pine and red maple with sucrose (bottom). Standard error is represented in italics $(n=4)$. Treatments that do not share the same letter are significantly different from each other $(\alpha=0.05)$.

\begin{tabular}{|c|c|c|c|c|c|c|c|c|c|c|c|c|c|c|c|c|c|c|}
\hline \multirow{2}{*}{$\begin{array}{l}\text { Treatment } \\
\text { JP wood }\end{array}$} & \multicolumn{3}{|c|}{$\begin{array}{l}\text { Total PyOM-C Mineralized } \\
\left(\mathrm{mg} \mathrm{C}^{-1} \text { Added C) }\right.\end{array}$} & \multicolumn{3}{|c|}{$\begin{array}{l}\text { Fast-Cycling C Pool } \\
\left(\mathrm{mg} \mathrm{C}^{-1} \text { Added C) }\right.\end{array}$} & \multicolumn{3}{|c|}{$\begin{array}{c}\text { Slow-Cycling C } \\
\text { Pool (mg C g }{ }^{-1} \text { Added C) }\end{array}$} & \multicolumn{3}{|c|}{$\mathrm{MRT}_{\mathrm{f}}$ (days) } & \multicolumn{3}{|c|}{$\mathrm{MRT}_{\mathrm{s}}$ (years) } & \multicolumn{3}{|c|}{ PyOM $_{w}$ (mg C) } \\
\hline & 560.66 & 75.4 & a & 214.1 & 4.8 & $\mathrm{a}$ & 403.9 & 31.7 & $\mathrm{a}$ & 10.0 & 1.1 & a & 2.7 & 0.9 & $\mathrm{a}$ & 4.1 & 0.3 & $\mathrm{~b}$ \\
\hline JP T200 & 302.1 & 65.9 & $\mathrm{~b}$ & 45.5 & 1.1 & $c^{*}$ & 249.0 & 7.4 & $c^{*}$ & 6.1 & 1.3 & $\mathrm{~b}$ & 8.0 & 4.3 & $b^{*}$ & 2.3 & 0.2 & d \\
\hline JP T300 & 41.3 & 6.0 & $\mathrm{~d}$ & 6.3 & 0.8 & $e^{*}$ & 29.2 & 1.2 & $e^{*}$ & 6.6 & 1.2 & $\mathrm{~b}$ & 40.0 & 4.2 & c & 0.8 & 0.1 & $\mathrm{f}$ \\
\hline JP T450 & 6.6 & 0.5 & e & 2.3 & 1.8 & $\mathrm{f}$ & 5.1 & 0.8 & $\mathrm{f}$ & 2.2 & 0.4 & c & 292.3 & 45.6 & d & 0.2 & 0.0 & $\mathrm{~g}$ \\
\hline JP T600 & 6.6 & 1.7 & e & 1.4 & 0.0 & $\mathrm{f}$ & 5.0 & 1.0 & $\mathrm{f}$ & 1.7 & 1.0 & c & 343.3 & 72.1 & $\mathrm{~d}$ & 0.2 & 0.0 & $\mathrm{~g}$ \\
\hline RM wood & 488.3 & 20.7 & a & 99.4 & 4.9 & $b^{*}$ & 432.3 & 22.0 & $a *$ & 2.4 & 0.3 & c & 3.4 & 0.7 & a & 6.5 & 0.4 & a \\
\hline RM T200 & 351.2 & 40.4 & $\mathrm{~b}$ & 46.1 & 1.2 & $c^{*}$ & 309.6 & 23.0 & $b^{*}$ & 2.5 & 0.5 & c & 4.2 & 0.9 & a & 4.5 & 0.3 & c \\
\hline RM T300 & 150.8 & 16.5 & c & 19.7 & 0.5 & $\mathrm{~d}$ & 136.6 & 9.1 & $d^{*}$ & 1.8 & 0.2 & c & 8.9 & 1.1 & $\mathrm{~b}$ & 2.4 & 0.2 & $\mathrm{e}$ \\
\hline RM T450 & 7.4 & 0.9 & e & 3.3 & 0.2 & $\mathrm{f}$ & 4.5 & 0.4 & $\mathrm{f}$ & 1.2 & 0.3 & c & 281.1 & 54.2 & $d^{*}$ & 0.2 & 0.0 & $\mathrm{~g}$ \\
\hline RM T600 & 6.0 & 1.4 & $\mathrm{e}$ & 2.5 & 0.1 & $\mathrm{f}$ & 3.9 & 0.2 & $\mathrm{f}$ & 1.3 & 0.0 & c & 242.4 & 21.3 & $e^{*}$ & 0.2 & 0.0 & $\mathrm{~g}$ \\
\hline JPS wood & 686.2 & 58.5 & a & 174.0 & 10.1 & $\mathrm{a}$ & 533.8 & 44.6 & $\mathrm{a}$ & 9.9 & 1.1 & $\mathrm{a}$ & 1.6 & 0.3 & $\mathrm{a}$ & 4.1 & 0.3 & b \\
\hline JPS T200 & 345.4 & 25.4 & $\mathrm{~b}$ & 62.9 & 0.2 & $c^{*}$ & 293.3 & 8.2 & $b^{*}$ & 6.1 & 1.3 & $\mathrm{~b}$ & 4.1 & 0.6 & $a *$ & 2.3 & 0.2 & d \\
\hline JPS T300 & 31.0 & 1.9 & d & 13.4 & 1.5 & $\mathrm{e}^{*}$ & 18.5 & 1.8 & $d^{*}$ & 8.0 & 2.0 & $\mathrm{~b}$ & 64.0 & 7.7 & c & 0.8 & 0.1 & $\mathrm{f}$ \\
\hline JPS T450 & 7.0 & 0.6 & e & 1.7 & 0.2 & $\mathrm{f}$ & 5.5 & 0.4 & $\mathrm{e}$ & 2.2 & 0.4 & c & 246.0 & 29.8 & d & 0.2 & 0.0 & $\mathrm{~g}$ \\
\hline JPS T600 & 6.3 & 2.0 & e & 1.8 & 1.0 & $\mathrm{f}$ & 4.7 & 0.2 & $\mathrm{e}$ & 2.3 & 0.8 & c & 333.4 & 73.2 & d & 0.2 & 0.0 & $\mathrm{~g}$ \\
\hline RMS wood & 611.5 & 29.8 & a & 71.3 & 2.6 & $b^{*}$ & 559.3 & 30.2 & $a *$ & 2.3 & 0.3 & c & 2.0 & 0.6 & a & 6.5 & 0.4 & a \\
\hline RMS T200 & 328.5 & 24.8 & $\mathrm{~b}$ & 52.7 & 1.6 & $c^{*}$ & 286.2 & 6.6 & $b^{*}$ & 2.4 & 0.5 & c & 3.9 & 0.5 & a & 4.5 & 0.3 & c \\
\hline RMS T300 & 102.2 & 11.6 & c & 18.9 & 1.0 & $\mathrm{~d}$ & 86.5 & 5.3 & $d^{*}$ & 2.0 & 0.2 & c & 12.7 & 2.0 & $\mathrm{~b}$ & 2.4 & 0.2 & $\mathrm{e}$ \\
\hline RMS T450 & 6.2 & 0.3 & $\mathrm{e}$ & 3.1 & 0.1 & $\mathrm{f}$ & 3.3 & 0.4 & $\mathrm{e}$ & 1.6 & 0.2 & c & 437.3 & 27.0 & $e^{*}$ & 0.2 & 0.0 & $\mathrm{~g}$ \\
\hline RMS T600 & 6.5 & 1.0 & e & 2.4 & 0.1 & $\mathrm{f}$ & 4.3 & 0.6 & e & 1.4 & 0.0 & c & 332.9 & 50.9 & $e^{*}$ & 0.2 & 0.0 & $\mathrm{~g}$ \\
\hline
\end{tabular}

* Asterisks indicate significant sucrose effects $(\alpha=0.05)$. 


\section{Results}

\subsection{PyOM Production Temperature Controls Mineralization}

Pyrolysis temperature had the greatest effect on mineralization for low temperature treatments (wood-T300). Specifically, net, fast-cycling, and slow cyling PyOM C mineralization rates progressively declined from wood to T300 for both JP and RM ( $p<0.05)$ (Table 2; Figure 1). Meanwhile, T450 and T600 mineralization rates were significantly lower than T300 for both JP and RM $(p<0.05)$. PyOM-C mineralization was not significantly different between T450 and T600 ( $p>0.05)$.
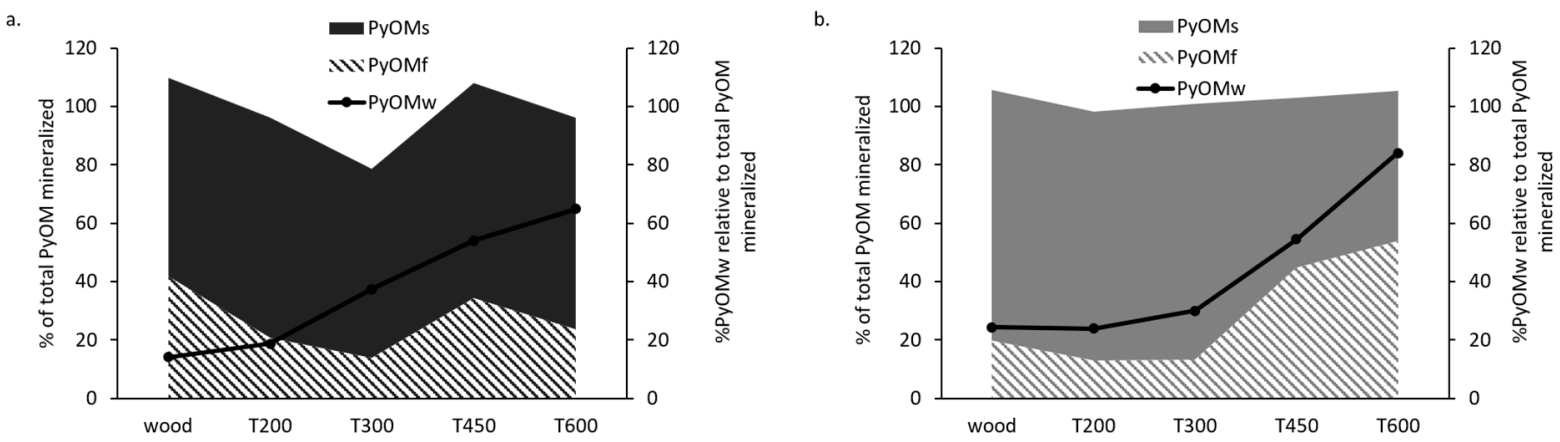

Figure 1. Fast $\left(\mathrm{PyOM}_{\mathrm{f}}\right)$ and slow $\left(\mathrm{PyOM}_{\mathrm{s}}\right)$ cycling $\mathrm{C}$ (left $y$ axis) plotted with leachable $\mathrm{C}\left(\mathrm{PyOM}_{\mathrm{w}}\right)$ (right $y$ axis) across temperature ( $x$ axis) for JP (a) and RM (b). Standard errors for the fast- and slow-cycling PyOM pools are presented in Table 2.

The MRT of the fast- and slow-cycling C pools for RM PyOM did not change with the temperature of production ( $p>0.05$; Figure 2). In contrast, the MRT of the fast-cycling pool of JP changed as follows: wood $>$ T200 and T300 > T450 = T600 $(p<0.05)$. Conversely, the percent potential contribution of $\mathrm{PyOM}_{\mathrm{w}}$ to net PyOM mineralized increased with increasing PyOM production temperature (Figure 1, Table S2). The percent potential contribution of $\mathrm{PyOM}_{\mathrm{W}}$ to net PyOM mineralization also exceeded the percent contribution of fast-cycling PyOM to net PyOM mineralization for all treatments except JP wood (Figure 1; Table S2).
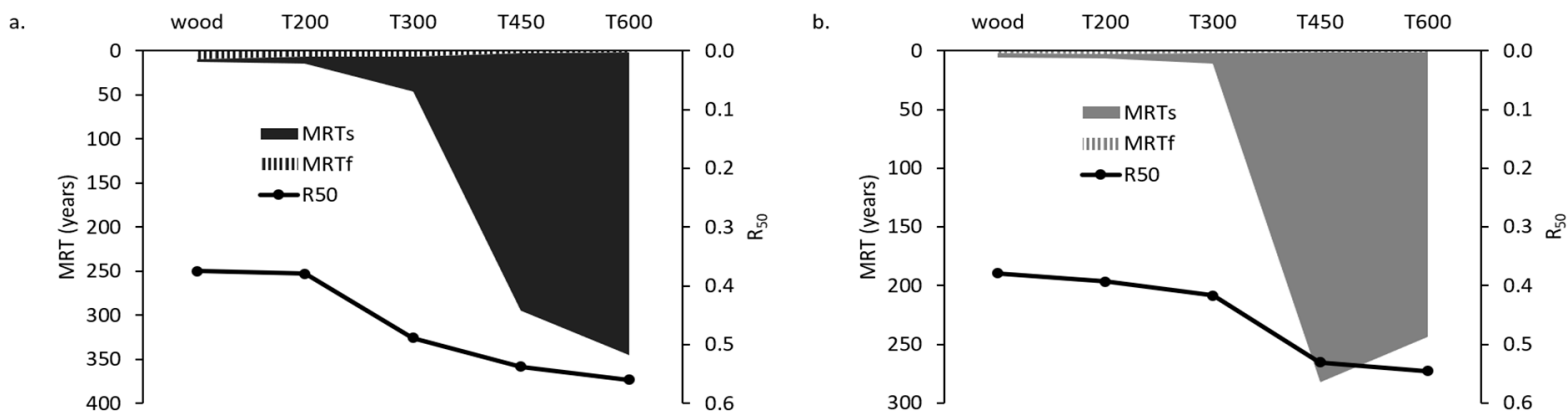

Figure 2. MRT of the fast $\left(\mathrm{MRT}_{\mathrm{f}}\right)$ and slow $\left(\mathrm{MRT}_{\mathrm{s}}\right)$ cycling $\mathrm{C}$ pools (left $y$ axis) plotted with the recalcitrance index $\left(\mathrm{R}_{50}\right)$ (right $y$ axis) across temperature ( $x$ axis) for JP (a) and RM (b). Standard errors for the fast- and slow-cycling PyOM MRTs are presented in Table 2.

\subsection{Linking Physiochemical Structure and PyOM Mineralization}

Regression of the physiochemical structure of PyOM versus PyOM-C mineralization rate and MRT resulted in significant correlations $\left(\mathrm{r}>0.7\right.$; Tables S3 and S4). The recalcitrance index $\left(\mathrm{R}_{50}\right)$ positively correlated with PyOM MRT $\mathrm{M}_{\mathrm{s}}$ across the temperature gradient for all treatments except JP without sucrose, which resulted in a moderate positive correlation (Table S3). The MRT of the JP fast-cycling 
C pool negatively correlated with SUVA while the slow-cycling C MRT positively correlated with SUVA (Table S3). There were no significant correlations between SUVA and the MRT of RM PyOM. $\mathrm{PyOM}_{\mathrm{W}}$ and the size of the fast- and slow-cycling C pools were positively correlated for JP and RM, whereby mineralization increased as $\mathrm{PyOM}_{\mathrm{W}}$ increased (Tables S3 and S4). Fast-cycling C correlated with non-lignin phenol content for RM across the temperature gradient, demonstrating a positive relationship between fast-cycling $C$ turnover and non-lignin phenol content (mineralization declined with non-lignin phenol content; Tables S3 and S4). The fast-cycling C pool and \% carbohydrate composition were positively correlated for RM only (Tables S3 and S4). Energy density negatively correlated with fast-cycling C (i.e., mineralization declined with increasing energy density) for RM $(\mathrm{r}>0.7$; Tables S3 and S4). There were no significant correlations between long-chain aliphatics and mineralization rates or MRT $(r<0.7)$.

\subsection{Influence of Source Taxa on PyOM Mineralization}

JP wood had higher fast-cycling C mineralization than RM, while JP T300 was significantly lower $(p<0.05)$. The MRTs of the fast-cycling $C$ pool for RM wood-T300 were significantly lower than those for JP wood-T300 (Table 2). For the slow-cycling C pool, this difference was only significant at T200 and T300 and was reflected in pool size $(p<0.05)$ (Table 2). However, the slow-cycling C MRT was significantly slower for JP T200, T300, and T450 than that for RM $(p<0.05$; Figure 2$)$. The potemtial $\mathrm{RM} \mathrm{PyOM}_{\mathrm{w}}$ contribution to the net PyOM mineralization was higher on average than JP $\mathrm{PyOM}_{\mathrm{w}}$ across treatments (Figure 1; Table S2). However, the potential JP PyOM $\mathrm{w}_{\mathrm{w}}$ contribution to the net PyOM mineralization was higher than the fast-cycling PyOM contribution to the net PyOM mineralization by a greater margin than that for $\mathrm{RM} \mathrm{PyOM}_{\mathrm{w}}$ (Figure 1; Table S2).

\subsection{Influence of Sucrose on PyOM Mineralization}

Sucrose additions to soil significantly increased the size of the fast-cycling C pool for JP T200 and T300, while added sucrose decreased the size of this pool for RM wood $(p<0.05)$. Sucrose addition also significantly decreased the mineralization of fast-cycling C mineralization in RM T300 $(p<0.05)$. Sucrose had no effect on the MRT of JP or RM wood or PyOM $(p>0.05)$, nor on the relationship between the physiochemical characteristics and MRT or PyOM mineralization for either species.

\section{Discussion}

\subsection{Changes in Chemical Composition with Increased Pyrolysis Temperature Controls PyOM Mineralization Rate and MRT}

As hypothesized, our experiments show that the MRTs for PyOM from both source wood species increased with increasing pyrolysis temperature, and these values spanned decadal to centennial time scales ( $2-450$ years). The MRT estimates reported herein are consistent with some of the prior estimates across this pyrolysis temperate range ( 6 to 5500 years); however, our MRTs did not exceed 500 years $[7,11,51]$. Our results confirm that progressive carbonization with increasing PyOM pyrolysis temperature imparts greater resistance to $\mathrm{C}$ mineralization in soil, that pyrolysis temperature is the first-order control of PyOM stabilization, and that wood and PyOM decay occurs more rapidly in a soil in which the majority of the organic matter is weakly protected and vulnerable to microbial decay [41,52]. Conversely, and as expected, $\mathrm{PyOM}_{\mathrm{w}}$ content, net PyOM C mineralization, and the size of the fast and slow PyOM C pools declined with increasing temperature of production (Table 2). This is consistent with studies linking the degree of PyOM mineralization to PyOM lability, which, in turn, is expected to decline with increasing production temperature due to the presence of more stable, condensed aromatic $C[7,8,11,51,53]$. This is also corroborated by our results which show that $\mathrm{PyOM}_{\mathrm{w}}$ may contribute more than half of the net PyOM mineralized in higher PyOM temperature treatments (T450 and T600). Increases in potential $\mathrm{PyOM}_{\mathrm{w}}$ contributions to the net mineralization with increasing pyrolysis temperature also support this explanation (Figure 1). Zimmerman et al. [51] 
proposed that microbial communities responsible for degrading condensed aromatic $\mathrm{C}$ are likely oligotrophic, resulting in lower mineralization yields and slower turnover times of higher temperature $\operatorname{PyOM}\left(<400{ }^{\circ} \mathrm{C}\right)$. In contrast, microbial communities that exploit a wide range of substrates likely utilize the leachable $\mathrm{C}$ associated with PyOM produced at lower temperatures, resulting in faster mineralization rates and shorter turnover times. This concept is supported by recent studies that demonstrate the importance of Gram-positive bacteria and actinobacteria in the use of PyOM-derived C compared with the more labile precursor wood, which was used mostly by saprotrophic fungi $[17,18]$. Therefore, the mineralization or incorporation of wood or PyOM preferences by specific microbial groups may be limited by leachable $C$, which is reflected in the results of the current study.

\subsection{Plant Source Taxa Mediates MRT and Mineralization at Intermediate PyOM Pyrolysis Temperatures}

We detected interactive source taxa and production temperature effects on PyOM mineralization and showed that these differences are correlated with physiochemical differences imparted to PyOM by its initial wood source composition $(p=0.011)$. The influence of the wood source was greatest for PyOM T300 (Tables 2 and S2, Figure 1), where the net mineralization at T300 for JP was significantly lower $(\sim 4 \times)$ than that for RM, suggesting that the higher PyOM $_{\mathrm{w}}$ content $(\sim 3 \times)$ of RM T300 PyOM is primarily responsible for this difference. Our results are consistent with Bruun et al. [26], who found that short-term PyOM C mineralization in a loamy soil was nearly proportional to the estimated labile $C$ content. In our study, if we assume that leachable $C$ is labile, then the difference in $\mathrm{PyOM}_{\mathrm{w}}$ between JP and RM T300 does not adequately account for the difference in mineralization between these treatments. This suggests that leachable $C$ is not synonymous with labile $C$. Bruun et al. [26] discussed the importance of PyOM quality in its short-term ( 4 months) decomposition, specifically the proportion of PyOM carbohydrate C. In our study, the constituent proportions of carbohydrates and non-lignin phenols and possibly heat-resistant aliphatics [5] at this temperature may have influenced the microbial accessibility of PyOM. In fact, the ratios of aliphatic to carbohydrate contents in JP and RM T300 were 1.4 and 0.5, respectively, suggesting that the presence of aliphatic compounds in combination with carbonization at this temperature in JP is partly responsible for the significantly lower mineralization yields (Tables 1 and 2). This is consistent with reports that PyOM sources with lower lignin or aliphatic $\mathrm{C}$ contents and higher labile $\mathrm{C}$ content also had greater mineralization than PyOM materials with higher lignin or aliphatic $C$ contents and lower labile $C$ content $[28,54,55]$.

Contrary to our expectations, JP wood degraded much faster tha RM wood (i.e., more rapid fast-cycling $\mathrm{C}$ mineralization rates; Table 2) even though RM wood and PyOM had much higher carbohydrate and non-lignin phenol contents than JP. One possible explanation for this is the conversion of carbohydrates in RM wood into microbial biomass. Jiang et al. [56] reported an increased incorporation of PyOM C in the presence of sucrose into microbial biomass. Based on Hopkins et al. [57], we assumed that $25 \%$ of added sucrose $C$ was converted to biomass and that the remaining $\mathrm{C}$ was mineralized to $\mathrm{CO}_{2}$. It is possible that differences in the microbial growth can account for the difference between RM wood and JP wood mineralization. However, $53 \%$ less wood $\mathrm{C}$ was mineralized to $\mathrm{CO}_{2}$ in the presence of sucrose, suggesting that $\sim 25 \%$ less $\mathrm{RM}$ wood was mineralized or utilized to grow biomass. Therefore, increased oxidative enzyme activity with greater lignin content and the presence of non-lignin phenols are the most likely factors driving differences in wood decomposition. Taken together, these differences in mineralization relative to thermal transition support the framework presented by Keiluweit et al. [13] and Hatton et al. [5], whose work defines a nonlinear model of thermal transformation that depends on pyrolysis temperature and PyOM source to predict the biological reactivity of PyOM in soil.

\subsection{PyOM ${ }_{w}$ Content and Estimated PyOM Recalcitrance Correlate with PyOM Decomposition}

Our results address the direct relationship between specific measures of PyOM chemical composition for two different taxa over a pyrolysis temperate gradient with the dynamics of PyOM in soil. We demonstrate that thermal indices of recalcitrance and leachable $\mathrm{C}$ correlate with wood 
and PyOM mineralization and residence time and may predict the biological reactivity of PyOM. Specifically, $\mathrm{PyOM}_{\mathrm{w}}$ content directly influenced the short-term mineralization of PyOM-C or source wood-C, whereas $\mathrm{PyOM}_{\mathrm{w}}$ declined nonlinearly with increasing PyOM production temperature (Table S2). Simultaneously, the contribution of $\mathrm{PyOM}_{\mathrm{w}}$ to net PyOM mineralization increased with increasing PyOM production temperature (Figure 1). This is in agreement with Cotrufo et al. [58], who proposed a dominant, early DOC (or dissolved organic matter)-microbial pathway of litter decomposition through the respiration or incorporation into biomass of nonstructural compounds by soil microbes. Following this model, it is practical to use water-soluble $\mathrm{C}$ as a predictor of early PyOM decomposition. $\mathrm{PyOM}_{\mathrm{w}}$ content was also negatively correlated with $\mathrm{R}_{50}$ values, the strongest variable consistent with PyOM decay rates, for both species (Table S2, Figure 1). The inverse relationship between $\mathrm{PyOM}_{w}$ and $\mathrm{R}_{50}$ is in agreement with the same model of soil organic matter (SOM) formation by Cortrufo et al. [58], in which the fraction of $\mathrm{C}$ remaining after acid hydrolysis is the slowest to decay, as decay would require very high rates of oxidation. The potentially leachable $C$ contribution to the net wood and PyOM mineralization exceeded the fast-cycling PyOM mineralization. However, it contributed $\sim 14-65 \%$ of the net mineralization for JP and $24-84 \%$ in RM (Table S2). This leaves a substantial portion of PyOM that was not soluble and suggests that leachates can potentially induce the decomposition of other non-soluble PyOM through co-metabolism. The co-metabolic pathway of PyOM mineralization involves the induction of fungal and microbial oxidative enzyme activity by the presence of $\mathrm{PyOM}_{\mathrm{w}}$ or soluble soil organic matter, which then leads to the mineralization of insoluble PyOM either due to proximity or enhanced enzymatic activity $[59,60]$. In essence, it is possible that $\mathrm{PyOM}_{\mathrm{w}}$ can positively prime (enhance the mineralization rate of) insoluble PyOM in the absence of sucrose (labile C). Our results suggest that the potential positive priming of insoluble fractions of PyOM by $\mathrm{PyOM}_{w}$ is greater in higher-temperature PyOM treatments (T450 and T600), where the insoluble PyOM fraction is likely greater. This is in keeping with our previous study that showed that artificially aged PyOM, which was thought to have significant amounts of leachable $C$, induced the enhanced oxidative enzyme response from white-rot fungi in a single culture while not being degraded itself [22]. We attributed the lack of decomposition in Reference [22] to the absence of a soil microbial consortia (present here in this study), which may benefit from the oxidative enzyme response of fungi can could lead to the further solubilization of PyOM for direct metabolism by bacterial groups [17-19,23].

In our experiment, we also assumed that chemical and structural recalcitrance, usually determined by resistance to acid hydrolysis, ultraviolet, ozone, or other harsh chemical oxidation of organic matter or PyOM [21,61,62], can also be inferred by thermal stability. Therefore, our data support the assertion by Plante et al. [63] and Harvey et al. [64] that the stability of wood and PyOM can be predicted by its level of thermal stability, whereby the higher the energy density or $R_{50}$, the lower the decomposition potential of a particular type of organic matter (Table S3, Figure 1). These two predictive indices suggest a thermodynamically mediated pathway to PyOM stabilization and a short-term microbially mediated pathway to PyOM loss in this soil system.

While PyOM $_{w}$ content and thermal stability may be the primary predictive measures of PyOM decomposition rates, other measures, specifically carbohydrate and non-lignin phenol contents and SUVA (an indicator of aromatic $\mathrm{C}$ in $\mathrm{PyOM}_{\mathrm{W}}$ ), may be useful in predicting the mode or mechanism of decomposition. Carbohydrate and non-lignin phenol contents correlated strongly with the mineralization of PyOM as well as $\mathrm{PyOM}_{\mathrm{w}}$ content in RM samples, whereas SUVA correlated strongly with the MRT of the slow-cycling pool in JP treatments (Table S3). With this information, we can propose which dominant enzyme systems (oxidative vs hydrolytic), microbial C acquisition strategies (oligotrophic vs heterotrophic; fungal vs microbial), or C-use efficiencies are likely associated with differences in PyOM decay dynamics between PyOM produced at different temperatures or with different woody species. One such example is the significant decrease in PyOM mineralization at T200 for both species (Table 1). Nearly $14 \%$ and $42 \%$ of non-lignin phenols were lost at T200 during pyrolysis. This is extremely important to consider as low-molecular-weight non-lignin phenols may act as secondary metabolites such as veratryl alcohol, which can enhance the oxidative decay process 
by saprotrophic fungi $[65,66]$. Declines in primary substrate availability and secondary metabolites should intuitively lead to decreases in substrate decomposition and could explain the decreases observed at PyOM T200 in this study. The presence of non-lignin phenols may partly explain the decline in mineralization at T200 for both species. Moreover, the decline in aliphatic $\mathrm{C}$ may also be implicit in marked decreases in decomposition, despite correlating weakly with the fast-cycling $\mathrm{C}$ pool. This suggests that though all of the tested parameters are not suitable predictors of PyOM reactivity, they may still be useful in determining the dynamic controls of PyOM mineralization in soil.

\subsection{Labile C Addition has a Minor Effect on PyOM Decomposition}

Sucrose additions to soil did not affect the $\mathrm{C}$ mineralization rates of RM or JP wood in soil. Added sucrose also had no effect on C mineralization from all RM PyOM, as well as JP T450 and JP T600 PyOM in soil. These results were contrary to our hypothesis that higher-temperature PyOM-C mineralization would be enhanced by sucrose addition, which would act as a co-metabolite and stimulate PyOM decay $[31,56]$. We also had not predicted the decrease in the slow-cycling C pool size in RM T300 (Table 2). Though minor, these subtle changes highlight the importance of a labile $\mathrm{C}$ substrate such as a simple carbohydrate in PyOM turnover [26,51]. Our results also demonstrate how the natural addition of a labile substrate may negate some physiochemical controls of PyOM mineralization if added in significant quantities $[7,29]$. However, it is also essential to note that the sucrose addition rate in this study was very low compared to those of other studies. Additionally, the soil used in this study is low in C $(\sim 0.5 \% \mathrm{C}, 0-25 \mathrm{~cm})$, much of the organic C is physically unprotected [48], and it is chemically and physically different from organic rich soils with higher $\mathrm{N}$ availability where acquisition activities may vary $[8,48]$.

\section{Conclusions}

PyOM physiochemical structure related to plant source taxa and pyrolysis temperature was directly linked to its $C$ mineralization rate in a coarse-textured, north temperate forest soil. This study demonstrated that pyrolysis temperature is the major mediator of wood and PyOM mineralization rate and MRT, acting through more complete carbonization with increasing PyOM pyrolysis temperature, leachable $\mathrm{C}$ content, and leachable $\mathrm{C}$ contribution to net PyOM mineralization. We also found that the MRTs of PyOM range from decadal to centennial time scales in a soil with weak physical protection through SOM-mineral complexation. In this study, the effects of labile $\mathrm{C}$ addition on PyOM decomposition dynamics were infrequent and minor, suggesting little co-metabolic stimulation of PyOM decay in this soil. Plant taxa effects were most pronounced at the intermediate pyrolysis temperatures, where differences in the physiochemical structure were greatest. Lastly, we showed that thermal stability and leachable $\mathrm{C}$ content are strong predictors of wood and PyOM decay rates in soil and that leachable PyOM may induce the co-metabolism of insoluble PyOM. Inquiries on the extent of incorporation of wood and PyOM C into microbial biomass are necessary to more accurately explain shifts in mineralization between the fast- and slow-cycling $\mathrm{C}$ pools in the presence and absence of another labile $\mathrm{C}$ source, such as sucrose. This information can be used to develop models linking microbial utilization, mineralization, $\mathrm{C}$ pool sizes, and MRT with wood and PyOM chemical composition and thermal stability.

Supplementary Materials: The following are available online at http:/ /www.mdpi.com/2571-8789/2/3/48/s1, Table S1: Web of science query results, unfiltered for isotopes, soil, chemical characterization, or PyOM type; Table S2: \% Contribution of fast-cycling PyOM $\left(\mathrm{PyOM}_{\mathrm{f}}\right)$, slow-cycling PyOM $\left(\mathrm{PyOM}_{\mathrm{s}}\right)$, and leachable wood and PyOM $\left(\mathrm{PyOM}_{\mathrm{w}}\right)$ to net PyOM mineralization; and Table S3: Pearson correlation coefficients of tested parameters for (a) jack pine (JP) and (b) red maple (RM) wood and PyOM treatments.

Author Contributions: All authors contributed equally to the experimental design, experimentation, data analysis, and preparation of manuscript for publication.

Funding: This research was supported by the National Science Foundation (DEB-1127253) and the Purdue Climate Change Research Center. 
Acknowledgments: We are grateful to Ulyssa Hester, Madison Hughes, Cheng-Peng Hu, and Jake Winters for their assistance with mesocosm assembly and maintenance.

Conflicts of Interest: The authors declare no conflict of interest.

\section{References}

1. IPCC Climate Change. The Physical Science Basis. Contribution of Working Group I to the Fifth Assessment Report of the Intergovernmental Panel on Climate Change; Cambridge University: Cambridge, UK; New York, NY, USA, 2013.

2. Santín, C.; Doerr, S.H.; Kane, E.S.; Masiello, C.A.; Ohlson, M.; Rosa, J.M.; Preston, C.M.; Dittmar, T. Towards a global assessment of pyrogenic carbon from vegetation fires. Glob. Chang. Biol. 2016, 22, 76-91. [CrossRef] [PubMed]

3. Santín, C.; Doerr, S.H.; Preston, C.M.; González-Rodríguez, G. Pyrogenic organic matter production from wildfires: A missing sink in the global carbon cycle. Glob. Chang. Biol. 2015, 21, 1621-1633. [CrossRef] [PubMed]

4. Santos, F.; Fraser, M.P.; Bird, J.A. Atmospheric black carbon deposition and characterization of biomass burning tracers in a northern temperate forest. Atmos. Environ. 2014, 95, 383-390. [CrossRef]

5. Hatton, P.-J.; Chatterjee, S.; Filley, T.R.; Dastmalchi, K.; Plante, A.F.; Abiven, S.; Gao, X.; Masiello, C.A.; Leavitt, S.W.; Nadelhoffer, K.J.; et al. Tree taxa and pyrolysis temperature interact to control the efficacy of pyrogenic organic matter formation. Biogeochemistry 2016, 130, 103-116. [CrossRef]

6. Reich, P.B.; Sendall, K.M.; Rice, K.; Rich, R.L.; Stefanski, A.; Hobbie, S.E.; Montgomery, R.A. Geographic range predicts photosynthetic and growth response to warming in co-occurring tree species. Nat. Clim. Chang. 2015, 5, 148-152. [CrossRef]

7. Lehmann, J.; Abiven, S.; Kleber, M.; Pan, G.; Singh, B.P.; Sohi, S.P.; Zimmerman, A.R.; Lehmann, J.; Joseph, S. Persistence of biochar in soil. Biochar Environ. Manag. Sci. Technol. Implement. 2015, 2, 233-280.

8. Wang, J.; Xiong, Z.; Kuzyakov, Y. Biochar stability in soil: Meta-analysis of decomposition and priming effects. Gcb Bioenergy 2016, 8, 512-523. [CrossRef]

9. Weng, Z.; Van Zwieten, L.; Singh, B.P.; Kimber, S.; Morris, S.; Cowie, A.; Macdonald, L.M. Plant-biochar interactions drive the negative priming of soil organic carbon in an annual ryegrass field system. Soil Biol. Biochem. 2015, 90, 111-121. [CrossRef]

10. Schmidt, M.W.; Torn, M.S.; Abiven, S.; Dittmar, T.; Guggenberger, G.; Janssens, I.A.; Kleber, M.; Kögel-Knabner, I.; Lehmann, J.; Manning, D.A.; et al. Persistence of soil organic matter as an ecosystem property. Nature 2011, 478, 49-56. [CrossRef] [PubMed]

11. Singh, B.P.; Cowie, A.L.; Smernik, R.J. Biochar carbon stability in a clayey soil as a function of feedstock and pyrolysis temperature. Environ. Sci. Technol. 2012, 46, 11770-11778. [CrossRef] [PubMed]

12. Hammes, K.; Torn, M.S.; Lapenas, A.G.; Schmidt, M.W. Centennial black carbon turnover observed in a Russian steppe soil. Biogeosciences 2008, 5, 1339-1350. [CrossRef]

13. Keiluweit, M.; Nico, P.S.; Johnson, M.G.; Kleber, M. Dynamic molecular structure of plant biomass-derived black carbon (biochar). Environ. Sci. Technol. 2010, 44, 1247-1253. [CrossRef] [PubMed]

14. Chatterjee, S.; Santos, F.; Abiven, S.; Itin, B.; Stark, R.E.; Bird, J.A. Elucidating the chemical structure of pyrogenic organic matter by combining magnetic resonance, mid-infrared spectroscopy and mass spectrometry. Org. Geochem. 2012, 51, 35-44. [CrossRef]

15. Brodowski, S.; John, B.; Flessa, H.; Amelung, W. Aggregate-occluded black carbon in soil. Eur. J. Soil Sci. 2006, 57, 539-546. [CrossRef]

16. Liang, B.; Lehmann, J.; Solomon, D.; Sohi, S.; Thies, J.E.; Skjemstad, J.O.; Luizao, F.J.; Engelhard, M.H.; Neves, E.G.; Wirick, S. Stability of biomass-derived black carbon in soils. Geochim. Cosmochim. Acta 2008, 72, 6069-6078. [CrossRef]

17. Farrell, M.; Kuhn, T.K.; Macdonald, L.M.; Maddern, T.M.; Murphy, D.V.; Hall, P.A.; Singh, B.P.; Baumann, K.; Krull, E.S.; Baldock, J.A. Microbial utilisation of biochar-derived carbon. Sci. Total Environ. 2013, 465, $288-297$. [CrossRef] [PubMed]

18. Santos, F.; Torn, M.S.; Bird, J.A. Biological degradation of pyrogenic organic matter in temperate forest soils. Soil Biol. Biochem. 2012, 51, 115-124. [CrossRef] 
19. Wang, X.; Song, D.; Liang, G.; Zhang, Q.; Ai, C.; Zhou, W. Maize biochar addition rate influences soil enzyme activity and microbial community composition in a fluvo-aquic soil. Appl. Soil Ecol. 2015, 96, 265-272. [CrossRef]

20. Cheng, C.-H.; Lehmann, J.; Thies, J.E.; Burton, S.D.; Engelhard, M.H. Oxidation of black carbon by biotic and abiotic processes. Org. Geochem. 2006, 37, 1477-1488. [CrossRef]

21. Liu, Z.; Demisie, W.; Zhang, M. Simulated degradation of biochar and its potential environmental implications. Environ. Pollut. 2013, 179, 146-152. [CrossRef] [PubMed]

22. Gibson, C.; Berry, T.D.; Wang, R.; Spencer, J.A.; Johnston, C.T.; Jiang, Y.; Bird, J.A.; Filley, T.R. Weathering of pyrogenic organic matter induces fungal oxidative enzyme response in single culture inoculation experiments. Org. Geochem. 2016, 92, 32-41. [CrossRef] [PubMed]

23. Wang, R.; Gibson, C.D.; Berry, T.D.; Jiang, Y.; Bird, J.A.; Filley, T.R. Photooxidation of pyrogenic organic matter reduces its reactive, labile $C$ pool and the apparent soil oxidative microbial enzyme response. Geoderma 2017, 293, 10-18. [CrossRef]

24. Du, Z.; Wang, Y.; Huang, J.; Lu, N.; Liu, X.; Lou, Y.; Zhang, Q. Consecutive biochar application alters soil enzyme activities in the winter wheat-growing season. Soil Sci. 2014, 179, 75-83. [CrossRef]

25. Gibson, C.; Hatton, P.-J.; Bird, J.A.; Nadelhoffer, K.; Le Moine, J.; Filley, T. Tree taxa and pyrolysis temperature interact to control pyrogenic organic matter induced native soil organic carbon priming. Soil Biol. Biochem. 2018, 119, 174-183. [CrossRef]

26. Bruun, E.W.; Hauggaard-Nielsen, H.; Ibrahim, N.; Egsgaard, H.; Ambus, P.; Jensen, P.A.; Dam-Johansen, K. Influence of fast pyrolysis temperature on biochar labile fraction and short-term carbon loss in a loamy soil. Biomass Bioenergy 2011, 35, 1182-1189. [CrossRef]

27. Cross, A.; Sohi, S.P. The priming potential of biochar products in relation to labile carbon contents and soil organic matter status. Soil Biol. Biochem. 2011, 43, 2127-2134. [CrossRef]

28. Pereira, R.C.; Kaal, J.; Arbestain, M.C.; Lorenzo, R.P.; Aitkenhead, W.; Hedley, M.; Macías, F.; Hindmarsh, J.; Maciá-Agulló, J.A. Contribution to characterisation of biochar to estimate the labile fraction of carbon. Org. Geochem. 2011, 42, 1331-1342. [CrossRef]

29. Hamer, U.; Marschner, B.; Brodowski, S.; Amelung, W. Interactive priming of black carbon and glucose mineralisation. Org. Geochem. 2004, 35, 823-830. [CrossRef]

30. Kuzyakov, Y.; Bogomolova, I.; Glaser, B. Biochar stability in soil: Decomposition during eight years and transformation as assessed by compound-specific 14 C analysis. Soil Biol. Biochem. 2014, 70, 229-236. [CrossRef]

31. Wang, J.; Dokohely, M.E.; Xiong, Z.; Kuzyakov, Y. Contrasting effects of aged and fresh biochars on glucose-induced priming and microbial activities in paddy soil. J. Soils Sediments 2016,16, 191-203. [CrossRef]

32. Ryan, K.C. Dynamic interactions between forest structure and fire behavior in boreal ecosystems. Silva Fenn. 2002, 36, 13-39. [CrossRef]

33. Santín, C.; Doerr, S.H.; Merino, A.; Bryant, R.; Loader, N.J. Forest floor chemical transformations in a boreal forest fire and their correlations with temperature and heating duration. Geoderma 2016, 264, 71-80. [CrossRef]

34. Kleber, M.; Hockaday, W.; Nico, P.S. Characteristics of biochar: Macro-molecular properties. In Biochar for Environmental Management; Routledge: London, UK, 2015.

35. Cong, Z.; Kang, S.; Gao, S.; Zhang, Y.; Li, Q.; Kawamura, K. Historical Trends of Atmospheric Black Carbon on Tibetan Plateau As Reconstructed from a 150-Year Lake Sediment Record. Environ. Sci. Technol. 2013, 47, 2579-2586. [CrossRef] [PubMed]

36. Socher, S.A.; Prati, D.; Boch, S.; Müller, J.; Baumbach, H.; Gockel, S.; Hemp, A.; Schöning, I.; Wells, K.; Buscot, F. Others Interacting effects of fertilization, mowing and grazing on plant species diversity of 1500 grasslands in Germany differ between regions. Basic Appl. Ecol. 2013, 14, 126-136. [CrossRef]

37. Cumming, S.G.; Drever, C.R.; Houle, M.; Cosco, J.; Racine, P.; Bayne, E.; Schmiegelow, F.K. A gap analysis of tree species representation in the protected areas of the Canadian boreal forest: Applying a new assemblage of digital Forest Resource Inventory data 1. Can. J. For. Res. 2014, 45, 163-173. [CrossRef]

38. Sun, Y.; Gao, B.; Yao, Y.; Fang, J.; Zhang, M.; Zhou, Y.; Chen, H.; Yang, L. Effects of feedstock type, production method, and pyrolysis temperature on biochar and hydrochar properties. Chem. Eng. J. 2014, 240, 574-578. [CrossRef] 
39. Wang, S.; Gao, B.; Zimmerman, A.R.; Li, Y.; Ma, L.; Harris, W.G.; Migliaccio, K.W. Physicochemical and sorptive properties of biochars derived from woody and herbaceous biomass. Chemosphere 2015, 134, 257-262. [CrossRef] [PubMed]

40. Shortle, W.C.; Smith, K.T.; Jellison, J.; Schilling, J.S. Potential of decaying wood to restore root-available base cations in depleted forest soils. Can. J. For. Res. 2012, 42, 1015-1024. [CrossRef]

41. McFarlane, K.J.; Torn, M.S.; Hanson, P.J.; Porras, R.C.; Swanston, C.W.; Callaham, M.A.; Guilderson, T.P. Comparison of soil organic matter dynamics at five temperate deciduous forests with physical fractionation and radiocarbon measurements. Biogeochemistry 2012, 112, 457-476. [CrossRef]

42. De Groot, W.J.; Flannigan, M.D.; Cantin, A.S. Climate change impacts on future boreal fire regimes. For. Ecol. Manag. 2013, 294, 35-44. [CrossRef]

43. Bird, J.A.; Torn, M.S. Fine Roots vs. Needles: A Comparison of $13 \mathrm{C}$ and $15 \mathrm{~N}$ Dynamics in a Ponderosa Pine Forest Soil. Biogeochemistry 2006, 79, 361-382. [CrossRef]

44. Hammes, K.; Smernik, R.J.; Skjemstad, J.O.; Herzog, A.; Vogt, U.F.; Schmidt, M.W. Synthesis and characterisation of laboratory-charred grass straw (Oryza sativa) and chestnut wood (Castanea sativa) as reference materials for black carbon quantification. Org. Geochem. 2006, 37, 1629-1633. [CrossRef]

45. Fernández, J.M.; Peltre, C.; Craine, J.M.; Plante, A.F. Improved characterization of soil organic matter by thermal analysis using CO2/H2O evolved gas analysis. Environ. Sci. Technol. 2012, 46, 8921-8927. [CrossRef] [PubMed]

46. Ward, C.P.; Sleighter, R.L.; Hatcher, P.G.; Cory, R.M. Insights into the complete and partial photooxidation of black carbon in surface waters. Environ. Sci. Process. Impacts 2014, 16, 721-731. [CrossRef] [PubMed]

47. Weishaar, J.L.; Aiken, G.R.; Bergamaschi, B.A.; Fram, M.S.; Fujii, R.; Mopper, K. Evaluation of specific ultraviolet absorbance as an indicator of the chemical composition and reactivity of dissolved organic carbon. Environ. Sci. Technol. 2003, 37, 4702-4708. [CrossRef] [PubMed]

48. Gough, C.M.; Vogel, C.S.; Schmid, H.P.; Su, H.-B.; Curtis, P.S. Multi-year convergence of biometric and meteorological estimates of forest carbon storage. Agric. For. Meteorol. 2008, 148, 158-170. [CrossRef]

49. Gough, C.M.; Vogel, C.S.; Schmid, H.P.; Curtis, P.S. Controls on annual forest carbon storage: Lessons from the past and predictions for the future. Bioscience 2008, 58, 609-622. [CrossRef]

50. Žifčáková, L.; Větrovský, T.; Howe, A.; Baldrian, P. Microbial activity in forest soil reflects the changes in ecosystem properties between summer and winter. Environ. Microbiol. 2016, 18, 288-301. [CrossRef] [PubMed]

51. Zimmerman, A.R.; Gao, B.; Ahn, M.-Y. Positive and negative carbon mineralization priming effects among a variety of biochar-amended soils. Soil Biol. Biochem. 2011, 43, 1169-1179. [CrossRef]

52. Santos, F.; Nadelhoffer, K.; Bird, J.A. Rapid fine root $\mathrm{C}$ and $\mathrm{N}$ mineralization in a northern temperate forest soil. Biogeochemistry 2016, 128, 187-200. [CrossRef]

53. Zimmerman, A.R. Abiotic and microbial oxidation of laboratory-produced black carbon (biochar). Environ. Sci. Technol. 2010, 44, 1295-1301. [CrossRef] [PubMed]

54. Ippolito, J.A.; Spokas, K.A.; Novak, J.M.; Lentz, R.D.; Cantrell, K.B. Biochar elemental composition and factors influencing nutrient retention. In Biochar for Environmental Management: Science, Technology and Implementation, 2nd ed.; Routledge: New York, NY, USA, 2015; pp. 139-163.

55. Pignatello, J.J.; Uchimiya, M.; Abiven, S.; Schmidt, M.W. Evolution of biochar properties in soil. Biochar Environ. Manag. 2015, 1, 195-234.

56. Jiang, X.; Haddix, M.L.; Cotrufo, M.F. Interactions between biochar and soil organic carbon decomposition: Effects of nitrogen and low molecular weight carbon compound addition. Soil Biol. Biochem. 2016, 100, 92-101. [CrossRef]

57. Hopkins, F.M.; Filley, T.R.; Gleixner, G.; Lange, M.; Top, S.M.; Trumbore, S.E. Increased belowground carbon inputs and warming promote loss of soil organic carbon through complementary microbial responses. Soil Biol. Biochem. 2014, 76, 57-69. [CrossRef]

58. Cotrufo, M.F.; Soong, J.L.; Horton, A.J.; Campbell, E.E.; Haddix, M.L.; Wall, D.H.; Parton, W.J. Formation of soil organic matter via biochemical and physical pathways of litter mass loss. Nat. Geosci. 2015, 8, 776-779. [CrossRef]

59. Whitman, T.; Zhu, Z.; Lehmann, J. Carbon Mineralizability Determines Interactive Effects on Mineralization of Pyrogenic Organic Matter and Soil Organic Carbon. Environ. Sci. Technol. 2014, 48, 13727-13734. [CrossRef] [PubMed] 
60. Whitman, T.; Singh, B.P.; Zimmerman, A.R.; Lehmann, J.; Joseph, S. Priming effects in biochar-amended soils: Implications of biochar-soil organic matter interactions for carbon storage. Biochar Environ. Manag. Sci. Technol. Implement. 2015, 2, 455-488.

61. Skjemstad, J.O.; Clarke, P.; Taylor, J.A.; Oades, J.M.; McClure, S.G. The chemistry and nature of protected carbon in soil. Soil Res. 1996, 34, 251-271. [CrossRef]

62. Kawamoto, K.; Ishimaru, K.; Imamura, Y. Reactivity of wood charcoal with ozone. J. Wood Sci. 2005, 51, 6672. [CrossRef]

63. Plante, A.F.; Fernández, J.M.; Haddix, M.L.; Steinweg, J.M.; Conant, R.T. Biological, chemical and thermal indices of soil organic matter stability in four grassland soils. Soil Biol. Biochem. 2011, 43, 1051-1058. [CrossRef]

64. Harvey, O.R.; Kuo, L.-J.; Zimmerman, A.R.; Louchouarn, P.; Amonette, J.E.; Herbert, B.E. An index-based approach to assessing recalcitrance and soil carbon sequestration potential of engineered black carbons (biochars). Environ. Sci. Technol. 2012, 46, 1415-1421. [CrossRef] [PubMed]

65. Goodell, B.; Jellison, J.; Liu, J.; Daniel, G.; Paszczynski, A.; Fekete, F.; Krishnamurthy, S.; Jun, L.; Xu, G. Low molecular weight chelators and phenolic compounds isolated from wood decay fungi and their role in the fungal biodegradation of wood. J. Biotechnol. 1997, 53, 133-162. [CrossRef]

66. Zapanta, L.S.; Tien, M. The roles of veratryl alcohol and oxalate in fungal lignin degradation. J. Biotechnol. 1997, 53, 93-102. [CrossRef]

(C) 2018 by the authors. Licensee MDPI, Basel, Switzerland. This article is an open access article distributed under the terms and conditions of the Creative Commons Attribution (CC BY) license (http:/ / creativecommons.org/licenses/by/4.0/). 